\title{
Lack of cross-reactivity between antibody against smooth muscle and antibodies to measles virus in sera from patients with chronic active hepatitis
}

\author{
A-I SOMMER, G HAUKENES \\ From the Gade Institute, Department of Microbiology and Immunology, University of Bergen, Bergen, Norway
}

SUMMARY A majority of patients with HBsAg-negative chronic active hepatitis (CAH) show considerably raised titres of serum antibodies against measles virus antigens. Since these patients often have high titres of antiactin specific antibodies against smooth muscle, and since actin is also incorporated into the measles virion during replication, we have examined whether there was any cross-reactivity between the two antigen-antibody systems.

Cross-absorbtions of sera from patients with $\mathrm{CAH}$ were performed using measles virus antigens and smooth muscle from human uterus. The corresponding specific antibodies were removed from serum without significantly affecting the titres of the other antibodies. Absorption had no influence on the total amount of IgG in serum. The raised titres of antibodies against measles virus seen in $\mathrm{CAH}$ can therefore not be explained by cross-reaction with antibodies to smooth muscle.

Significantly raised and often extremely high antibody titres to measles and rubella viruses have been demonstrated in sera from patients with chronic active hepatitis $(\mathrm{CAH})$ not caused by hepatitis $B$ virus (HBV). ${ }^{1-4} \mathrm{~A}$ similar rise has not been seen in other chronic liver diseases. ${ }^{3}$

The first case described ${ }^{1}$ with an extremely high antibody titre in the rubella haemagglutination inhibition (HI) test was originally diagnosed as chronic persistent hepatitis, but turned out later to be $\mathrm{CAH}$. Antibodies to several other viruses have not been found to be similarly increased. ${ }^{35}$ High titres of autoantibodies, particularly against smooth muscle, are commonly associated with $\mathrm{HBsAg-negative}$ CAH. ${ }^{6}$ Moreover, raised serum IgG concentrations are found in most cases. There is, however, no obvious linear correlation between the IgG concentration and the titre of antibodies to rubella or measles viruses. ${ }^{3}$ There is doubt about the specificity of the viral antibodies concerned, and the possibility of cross-reactivity between antibody to measles virus and SMA has been suggested but no such evidence has been found. ${ }^{6}$

Smooth muscle antibodies (SMA) are a heterogeneous group of autoantibodies reactive with different smooth muscle autoantigens. ${ }^{8}$ As SMA in sera from patients with $\mathrm{CAH}$ show an antiactin specificity, ${ }^{90}$ and since actin is said to be

Accepted for publication 5 April 1982 incorporated into the measles virus particle, " there a theoretical possibility for cross-reactions caused bo contaminating host cell proteins. A possible crossreactivity between measles virus antibodies and autoantibodies has been investigated earlier by Triger et al. ${ }^{7}$ They absorbed sera from patients with $\mathrm{CAH}$ with a mixture of crude measles virus and Vero cells, and with Vero cells alone as a control. Measles antibody titres were measured using an indirect immunofluorescence technique, as they found the complement-fixation (CF) technique unsuitable after absorbtion of the sera with measles virus antigen.

In our investigation the measles virus antigens (MVA) used for absorption were purified, thereby minimising the effects of Vero cell components. The use of $\mathrm{HI}$ and $\mathrm{CF}$ techniques to measure the measles virus titres was made possible by first removing excess MVA and soluble antigen-antibody complexes that may have influenced the assays. Smooth muscle tissue used for the absorption of SMA was prepared by homogenising human uterus.

\section{Material and methods}

SERA

Sera were obtained from patients with $\mathrm{CAH}$. The diagnosis was established in each case by histological examination of a liver biopsy specimen. The criteria were those outlined by de Groote et al. ${ }^{12}$ All sera were 
HBsAg-negative. Pooled human serum (PHS) was obtained by mixing equal volumes of serum from 20 healthy blood donors.

\section{SMOOTH MUSCLE TISSUE}

Minced human uterus was washed in phosphatebuffered saline (PBS), $\mathrm{pH} 7 \cdot 2$ to remove blood. The mince was frozen at $-20^{\circ} \mathrm{C}$ and homogenised in a hydraulic press (X-press, AB Biox, Nacka, Sweden) at a pressure of $2000 \mathrm{~kg} / \mathrm{cm}^{2}(28000 \mathrm{psi})$.

\section{MEASLES VIRUS}

The Edmonston strain B of measles virus was obtained from the State Serum Institute, Copenhagen, and propagated in Vero cells (Flow Laboratories Ltd, Irvine, Scotland). The cells were grown in monolayers in Eagle's Minimum Essential Medium (MEM), (Gibco, Grand Island, NY) supplemented with $7 \%$ serum from newborn calves (Flow, mycoplasma-screened and heat-treated before use) and 1\% glutamine (crystalline, Sigma Chemical Co).

The cells were maintained in Eagle's MEM with $2 \%$ calf serum and infected with a fifth generation stock suspension of virus at an input multiplicity of infection of 0.003 . When the monolayer showed giant cell formation, but was still attached to the glass (usually after two to three days), the medium with extracellular virus was harvested. New medium was then applied and a second harvest was obtained on the following day.

\section{PURIFICATION OF VIRUS}

The medium with extracellular virus was clarified by centrifugation at $1400 \mathrm{~g}$ for $15 \mathrm{~min}$. The crude virus material was pelleted on top of $1 \mathrm{ml} 60 \%$ sucrose using a SW 27 rotor in a Spinco L265B ultracentrifuge (Beckman Instruments, Palo Alto, California). TRIS- $\mathrm{HCl}$ buffer, $0.05 \mathrm{M}, \mathrm{pH} 7 \cdot 8$, was used for dilution of the crude virus-sucrose suspension. This mixture was layered on top of discontinuous 60,50 and $30 \%$ sucrose gradients and centrifuged at $80000 \mathrm{~g}$ for $2.5 \mathrm{~h}$. The fractions in the $30-50 \%$ interphase showing highest haemagglutination (HA) titres, were collected, combined and placed on top of a continuous 60,50 and $30 \%$ sucrose gradient and centrifuged at $80000 \mathrm{~g}$ for $18 \mathrm{~h}$. This was followed by a second fractionation, and fractions with highest HA values were collected and combined. The virus was concentrated by centrifugation at $80000 \mathrm{~g}$ for $1 \mathrm{~h}$, and the pellet was resuspended in minimal amounts of PBS.

\section{HAEMAGGLUTINATION AND}

HAEMAGGLUTINATION INHIBITION TESTS

The HA activity was determined using $0.8 \%$ of
Rhesus monkey erythrocytes; HI antibodies were assayed by serial twofold dilutions of heat-inactivated serum and four HA units of a Tween-ether extract of measles virus, ${ }^{13}$ (Orad, Behringwerke AG, MarburgLahn, FRG). Microtitre equipment was used throughout.

\section{COMPLEMENT FIXATION TEST}

Serial twofold dilutions of heat-inactivated serum were mixed with MVA for CF test (Otio, Behringwerke AG) diluted $1 / 8$ for optimal reaction, using the microtitre technique. Complement (guinea pig serum) and amboceptor (rabbit antisheep erythrocyte serum) were used in dilutions previously determined in checkerboard titration to yield optimal conditions.

PEROXIDASE-LABELLING OF SMOOTH MUSCLE ANTIBODIES

Serial twofold dilutions of serum were applied on cryostat sections of rat stomach. Smooth muscle antibodies were determined by an antihuman IgG, IgA, IgM, kappa and lambda peroxidase conjugate produced in rabbit (Dako Immunoglobulins, Copenhagen) and stained with benyidine-tetrahydrochloride (Fluka AG, Buchs, Switzerland) in $0.05 M$ TRIS- $\mathrm{HCl}$ buffer, $\mathrm{pH} 7.8$ with $0.02 \% \mathrm{H}_{2} \mathrm{O}_{2}$.

\section{ROCKET IMMUNOELECTROPHORESIS}

Rocket immunoelectrophoresis was carried out according to Christie et al $^{14}$ using Triton X100 treated cell-associated MVA and appropriate dilutions of sera estimated by pilot experiments.

\section{ABSORPTION PROCEDURE}

In order to remove SMA, $1.5 \mathrm{ml}$ serum diluted $1 / 4$ was absorbed with $2.0 \mathrm{~g}$ homogenised smooth muscle tissue suspended in $0.5 \mathrm{ml}$ PBS.

To remove $\mathrm{HI}$ antibodies to measles virus, the serum was absorbed with an equal volume of a purified, intact measles virus suspension showing an HA titre of 64 .

Cell-associated MVA for CF test (Behringwerke) was suspended in $1 \mathrm{ml}$ PBS. One volume of serum was mixed with nine volumes of antigen having an HA titre of 16 .

The controls consisted of sera diluted in PBS and treated in the same way. Bacterial growth was prevented by adding $1 \% \mathrm{NaN}_{3}$ to all sera. All sera were incubated by being shaken for $45 \mathrm{~min}$ at $37^{\circ} \mathrm{C}$ followed by overnight incubation at $4^{\circ} \mathrm{C}$.

After being absorbed the SMA-absorbed serum was centrifuged at $900 \mathrm{~g}$ for $15 \mathrm{~min}$ and the supernatant was collected. The final dilution of serum was calculated to be $1 / 8$. To remove excess of haemagglutinin after the absorption of $\mathrm{HI}$ antibodies, 
the serum-measles virus mixture was further absorbed for $15 \mathrm{~min}$ in iced water with a volume of packed Rhesus monkey erythrocytes equal to that of undiluted serum. After centrifugation at $900 \mathrm{~g}$ for 10 min the supernatant was collected. The serum dilution was now 1/4. After the absorption of CF antibodies, serum mixed with CF antigen to $0.5 \mathrm{ml}$ was placed on top of $4.5 \mathrm{ml} 30 \%$ sucrose, and centrifuged at $80000 \mathrm{~g}$ for $3.5 \mathrm{~h}$ to separate antigenantibody complexes from free antibodies. The $0.8 \mathrm{ml}$ at the top of the tube was then collected and had an end-dilution of $1 / 16$.

\section{Results}

It appeared from pilot experiments that it was difficult to prepare sufficient amounts of nucleoprotein (NP) for absorption from purified extracellular virus. Attempts were also made to attach NP to a solid phase (polyethylene tube) to prevent formation of soluble antigen-antibody complexes. Also in this case the amount of antigen appeared to be too small for absorption. We therefore had to resort to cell-associated measles virus which contains much more NP than extracellular purified measles virus. ${ }^{15}$

\section{ABSORPTION WITH HOMOGENISED SMOOTH MUSCLE}

The absorbed and non-absorbed patient sera were examined for SMA and measles virus $\mathrm{HI}$ and $\mathrm{CF}$ antibodies. Titration of SMA was started at a serum dilution of $1 / 16$. Serum absorbed with homogenised smooth muscle removed at least $80-90 \%$ of SMA, without any reduction of the $\mathrm{CF}$ or $\mathrm{HI}$ antibody titres (Table 1).

Table 1 Antibody titres before and after absorption of a $C A H$ serum with smooth muscle tissue

\begin{tabular}{llll}
\hline Serum & SMA & \multicolumn{2}{l}{ Measles } \\
\cline { 3 - 4 } & & $C F$ & $H I$ \\
\hline $\begin{array}{l}\text { Non-absorbed } \\
\text { Absorbed }\end{array}$ & 64 & 128 & 64 \\
\hline
\end{tabular}

The total content of IgG in the serum before and after absorption was determined by single radial immunodiffusion and compared with that of PHS. The IgG value of the CAH serum was not significantly raised when compared to PHS, and removal of SMA had no influence on the total IgG in serum.

\section{ABSORPTION WITH PURIFIED, INTACT}

MEASLES VIRUS

Incubation of the patient serum with purified, whole measles virus removed almost all $\mathrm{HI}$ antibodies (Table 2). Removal of $\mathrm{HI}$ antibodies had no influence on the CF antibody or the SMA titre (Table 2).

Table 2 Antibody titres in non-absorbed CAH serum and serum absorbed with purified intact $M V$

\begin{tabular}{|c|c|c|c|}
\hline \multirow[t]{2}{*}{ Serum } & \multirow[t]{2}{*}{$S M A$} & \multicolumn{2}{|c|}{ Measles } \\
\hline & & $C F$ & $H I$ \\
\hline $\begin{array}{l}\text { Non-absorbed } \\
\text { Absorbed }\end{array}$ & $\begin{array}{l}128 \\
128\end{array}$ & $\begin{array}{l}128 \\
128\end{array}$ & $\begin{array}{r}128 \\
4\end{array}$ \\
\hline
\end{tabular}

ABSORPTION WITH CELL-ASSOCIATED MVA Absorption of the patient serum with MVA for CF test (Behringwerke) resulted in almost total removal of CF antibodies (Table 3).

Table 3 Antibody titres in $C A H$ serum before and after absorption with cell-associated $M V A$

\begin{tabular}{|c|c|c|c|}
\hline \multirow[t]{2}{*}{ Serum } & \multirow[t]{2}{*}{$S M A$} & \multicolumn{2}{|c|}{ Measles } \\
\hline & & $C F$ & $H I$ \\
\hline $\begin{array}{l}\text { Non-absorbed } \\
\text { Absorbed }\end{array}$ & $\begin{array}{r}128 \\
64\end{array}$ & $\begin{array}{l}128 \\
\leqslant 8\end{array}$ & $\begin{array}{l}64 \\
16\end{array}$ \\
\hline
\end{tabular}

It is furthermore seen that some $\mathrm{HI}$ antibodies were also removed. This was expected as the MVA also contained some HA antigen.

The SMA titre was reduced with one dilution step after the absorbtion. This is, however, not a significant reduction.

Rocket immunoelectrophoresis was carried out with a CAH serum before and after absorption with cell-associated measles virus. It revealed that the NPline (previously determined by reaction of identity with purified $\mathrm{NP}^{14}$ ) was not present after the absorption.

\section{Discussion}

The cause of the raised antibody titres to measles virus and to smooth muscle in patients with $\mathrm{CAH}$ is at present not understood. ${ }^{2-46}$

Antibodies against some enterobacteria have also been found in raised titres. ${ }^{16}$ This can be attributed to an increased portal vein pressure resulting in increased release of antigenic material into the arterial circulation. It has also been suggested that the Kupffer cells may be functionally defective. This does not explain the occurrence of high antibody titres against measles virus, unless there is a continuous active production and release of MVA. The specificity of the antibodies concerned has been discussed and a cross-reaction with bacterial or autoantibodies has been suggested but never documented. ${ }^{6}$ 
The present study shows that absorption with homogenised smooth muscle gave no reduction in measles virus HI or CF titres, but removed SMA. As the removal of SMA had no influence on the total amount of IgG in serum, non-specific removal of IgG could be excluded.

Homogenised human uterus contains all the smooth muscle tissue proteins. It has been demonstrated that actin is the antigen reacting with SMA in sera from patients with CAH. ${ }^{910}$ As actin is one of the main proteins of Vero cells, measles virus was purified to minimise the effect of cell components.

The removal of $\mathrm{HI}$ antibodies by absorption with purified measles virus did not result in any loss of SMA or of CF antibodies. The amount of actin incorporated in virus was either too small to affect the SMA titre, or the actin was not exposed at the virus surface. CF antibodies may show both haemagglutinin and NP specificity, ${ }^{15}$ but are mainly directed against the NP of cell-associated measles virus and to a lesser degree against the haemagglutinin. Since the virus used for the absorption of $\mathrm{HI}$ antibodies was intact, the CF titre was, as expected, not reduced.

Other studies have shown difficulty in getting enough purified NP for the absorption of CF antibodies when using extracellular measles virus (unpublished data). In addition to the NP, MVA prepared from cell-associated virus can also contain haemagglutinin and host-cell proteins, which may influence the HI and the SMA titres. The cellassociated MVA used in this study removed most of the CF antibodies, and rocket immunoelectrophoresis showed that the NP-specific antibodies were absorbed from serum. We have thus not been able to show any cross-reactivity between antibody to smooth muscle and antibodies to the measles virus haemagglutinin and NP antigens in sera from patients with $\mathrm{CAH}$. It cannot, however, be excluded that there may be common, but restricted antigenic determinants which only can be detected by the use of monoclonal antibodies.

Studies of patients who developed $\mathrm{CAH}$ have shown that antibodies to both measles and rubella virus may rise significantly following the onset of liver disease. ${ }^{5}$ At present there is limited information about rubella virus antigens. The raised viral antibody titres seem to be closely connected with $\mathrm{CAH}$ and not just a result of a hypergammaglobulinaemia. ${ }^{3}$

One possible explanation of the raised antibody titres to measles virus is an increased antigen stimulation. Another explanation is a disturbance in the regulation of antibody producing lymphocytes. The demonstrated raised antibody response to both external and internal $\mathrm{MVA}^{1+}$ in $\mathrm{CAH}$ seems to indicate an increased antigenic stimulation because of reactivation of the virus or a release of viral antigens for other reasons. A selective disturbance in the regulation of clones of $B$ cells just specific for measles and rubella virus antigens, seems unlikely.

Only about a fourth of the cases of CAH in Norway are caused by hepatitis B virus. ${ }^{3}$ It is not known how many cases are due to non- $A$, non- $B$ viruses, but there is some evidence that non- $A$, non- $B$ viruses frequently lead to $\mathrm{CAH} .{ }^{17}$ It will be of interest to see if $\mathrm{CAH}$ caused by non- $\mathrm{A}$, non-B viruses differs from the other forms of $\mathrm{CAH}$ in antibody response to rubella and measles viruses.

\section{References}

' Closs O, Haukenes G, Bjark P, Pande $\mathrm{H}$. Unusually high titres of antibodies to rubella virus in a patient with chronic hepatitis. Scand J Infect Dis 1972;4:17-22.

2 Closs O, Haukenes G, Blomhoff JP, Gjone E. Raised antibody titres in chronic liver disease. Lancet 1971;ii:1202-3.

${ }^{3}$ Closs O, Haukenes G, Blomhoff JP, Gjone E. High titres of antibodies against rubella and morbilli virus in patients with chronic hepatitis. Scand J Gastroenterol 1973;8:523-8.

+ Laitinen O, Vesikari T. Chronic hepatitis with very high rubella and measles virus antibody titres. Lancet 1972;ii:1141.

$s$ Triger DR, Kurtz JB, MacCallum FO, Wright R. Raised antibody titres to measles and rubella virus in chronic active hepatitis. Lancet 1972;i:665-7.

- Triger DR. Bacterial, viral and autoantibodies in acute and chronic liver disease. Ann Clin Res 1976;8:174-81.

7 Triger DR, Kurtz JB, Wright R. Viral antibodies and autoantibodies in chronic liver disease. Gut 1974;15:94-8.

${ }^{*}$ Toh BH. Smooth muscle autoantibodies and autoantigens. Clin Exp Immunol 1979;38:621-8.

- Gabbiani G, Ryan GB, Lamelin JP, et al. Human smooth muscle autoantibody. Its identification as antiactin antibody and a study of its binding to "non-muscular" cells. Am J Pathol 1973;72: 473-88.

11) Lidman K, Biberfeld G, Fagraeus A, et al. Anti-actin specificity of human smooth muscle antibodies in chronic active hepatitis. Clin Exp Immunol 1976;24:266-72.

1 Tyrell DLJ, Norrby E. Structural polypeptides of measles virus J Gen Virol 1978;39:219-29.

12 Groote J de, Desmet VJ, Gedigk P, et al. A classification of chronic hepatitis. Lancet 1968;ii:626-8.

${ }_{13}$ Norrby E. Haemagglutination by measles virus. 4. A simple procedure for production of high potency antigen for haemagglutination-inhibition (HI) tests. Proc Soc Exp Biol Med 1962; 111:814.

${ }^{14}$ Christie KE, Haukenes G. Measles virus specific precipitins in sera from patients with chronic active hepatitis. Scand J Infect Dis 1979;11:99-106.

is Norrby E, Hammarskjøld B. Structural components of measles virus. Microbios 1972;5:17-29.

${ }^{16}$ Bjørneboe M, Prytz H, Orskov F. Antibodies to intestinal microbes in serum of patients with cirrhosis of the liver. Lancet 1972; i:58-60.

17 Weiland O. Hepatitis A. Aspects on prophylaxis and a comparison with hepatitis $B$ and hepatitis non-A, non-B on epidemiology and prognosis. Scand J Infect Dis [Suppl] 1981;28.

Requests for reprints to: Dr G Haukenes, Department of Microbiology and Immunology, University of Bergen, Bergen, Norway. 